Covered in: ERIH PLUS, CEEOL, Index Copernicus, CrossRef, CrossCheck, J-Gate, Google Scholar, Ideas RePeC, Econpapers, Socionet, KVK, WorldCat.

2019, Volume 7, Issue 1, pages: 91-95 | doi: 10.18662/lumenphs/20

\section{Towards a Philosophy of World Peace - „Vespasian V. Pella and the Ideal of Peace Through Law"}

\section{Alexandra HUIDU1}

${ }^{1} \mathrm{PhD}$ Student, LUMEN Research Center in Social and Humanistic Sciences, Iasi, Romania; Doctoral School of Sociology, University of Oradea, Romania, andra huidu@yahoo.com

\begin{abstract}
Some ideas are revolutionary for their time, and other ideas are indistinguishable from the reality that we have in our everyday life and which we take for granted, forgetting that at one time such ideas used to be revolutionary. This is the case of the ideal of peace through law which was the lifetime philosophy of the Romanian law scholar Vespasian V. Pella, an ideal whose development, from idea to practice, is pursued by the author Aurora Ciucă in the volume Vespasian V. Pella and the ideal of peace through law", published by Lumen Publishing House, in Iaşi, in 2019.
\end{abstract}

Keywords: international criminal law; international public law; Vespasian Pella; Aurora Ciucă.

How to cite: Huidu, A. (2019). Towards a Philosophy of World Peace - „Vespasian V. Pella and the Ideal of Peace Through Law". Logos Universality Mentality Education Novelty: Pbilosopby \& Humanistic Sciences, 7(1), 91-95. doi: 10.18662/lumenphs/20 
In a world that forgets it's heroes, who is looking for meaningless symbols that might be worthy of respect and admiration, in which young people are directed towards productivity rather than professional verticality and towards a conscience of each person's responsibility to contribute to the creation of a better society, for future generations to enjoy, jurist Vespasian Pella was, maybe not surprisingly, almost forgotten in his own country.

We say, "almost forgotten" because sometimes, through the care of dedicated professors - not only to transmitting scientific information, but also forming people of value, people with resources that not only can, but also want to take on their own struggle for a society augmented in the spirit of ethics and common human values - the name of Vespasian Pella was still pronounced in the amphitheatres of law faculties form universities with a rich academic tradition in Romania, even if only to stirr professional pride in younger generations of students.

And now we can say "saved from being forgotten" by this project of author Aurora Ciucă, with the support of the Vespasian V. Pella Association from Iaşi. An exceptional law scholar herself, the author took on a double task: that of a historian of law and a historian... of the future.

Of course, the photo-documentary album falls into the field of Romanian history of law, although ... Vespasian Pella is the law scholar who founded the field of international law in the form that is so familiar to us today, based on the idea of international justice, he is the global initiator of the concept of the law of peace, the first who promoted the idea of an international criminal law and establishing an International Criminal Court, he was part of the teams of specialists who drafted the first international conventions on terrorism and the repression of genocide, he supported the creation of the United Nations, and was the first diplomat who, alongside Aristide Briand, had the courage to say that it would be possible to create a European federal union (which we today call the European Union, a familiar interethnic organization, but which around the 1930s was not just a revolutionary concept, but an utopian one). Therefore, we can not say that the photo-documentary album about Vespasian V. Pella album falls only into the field of Romanian history of law, because it is correct to say that as long as Pella's ideas have affected the whole of Europe and not only, the volume can be as much part of the international history of law.

As we mentioned above, Aurora Ciuca tells us a story not only about the past (and sometimes she does that using images that, along with the text, have the gift of feeding the professional dignity of any jurist and the national pride of any Romanian who is not completely uprooted from their country ), but also about the future. Vespasian Pella's ideas are still actual, some of the 
Towards a Philosophy of World Peace - „Vespasian V. Pella and the Ideal of ...

projects he initiated have not yet been finalized, and some of his ideas come back to date with every war that starts, with every crime that is tried by an international criminal court, with each terrorist attack, with every application for EU membership, with each mediation of an interstate conflict made by the UN. Aurora Ciuca tells of the future that is not impossible, in which Romanian diplomacy could win, as former diplomat Vespasian Pella did, the respect of an entire international community in which promoting common values can be reinvigorated by remembering those who were and can still be an example.

And Pella may seem an that could be difficult (or even impossible) to follow by a young law student, a jurist in training who is still at the early beginning of their career, but who should not forget that Vespasian Pella was once a student in the same university (Alexandru Ioan Cuza University from Iassi, Romania) and went on a journey armed with an ideal, with an idea, which at that time, between the two World Wars, seemed equally difficult (if not impossible) to promote without being considered an utopian dreamer, and even more difficult to put into practice. But still, all these considered, today we have an International Criminal Court, we have the United Nations, we have the European Union, we have treaties to fight terrorism, we have convicted war criminals, and armed aggression is being outlawed in international law.

Romanian legal professions need such examples to remember that the lawyer, the judge or the prosecutor is not just an interpreter of the law, but a fine observer of the trends in society, of "social diseases", a person of fine culture and education who has a privileged position, specifically to know how the mechanism works from within, which gives the professionist not only vision, but also ethical responsibility towards all those who have neither the privilege, nor the moral obligation that comes along with that privilege, to promote public good for the all the members of society. This is the assumed task - as a lifetime profession - by Vespasian Pella, and this is the example of a fierce struggle for change that the Romanian jurist leaves as his inheritance to current generations.

Assuming the fight when almost no one believed in it, and certainly fewer were those who had the courage to assert it publicly, led to the nomination of Vespasian Pella for the Nobel Peace Prize in 1926, a prize he lost in favor to two other leading diplomats, Aristide Briand (Prime Minister of France) and Gustav Stresemann (German Foreign Affairs Minister), whose efforts were thus recognized for the negotiation of the Locarno Peace Treaty between France and Germany following the First War World. Later, 
Aristide Briand played an essential role in signing the famous 1927 BriandKellogg pact between Germany, France and the United States.

If the second part of the volume is precisely about this prestigious international activity of Vespasian Pella as a diplomat, a period about which we have information both from national and international sources, the first part of the volume very interestingly deals with "bringing to light", in its own right, from the repository of the National Archives Center form Iasi, information and documents about the life and career debut of young Pella, his family and education, the period of his studies in Iasi, and then his teaching career at the Law School of Al. I. Cuza University from Iasi. This is a stage of his life about which, until the appearance of this volume, the history of law recorded little and sometimes contradictory information. It is all the more meritorious that the author of the book took up the effort to complete the puzzle of Pella's life with this period, a period that was documented, "photographed" and presented to the reader as a story in images.

It is a story of an ideal, of peace, of a new ideology, that of justice, of a philosophy of life, that of the struggle against aggression, transformed into a true philosophy of international law, whose principles have fundamentally changed after the intervention on the international diplomacy plan of the jurist Vespasian Pella. Ideas that can fundamentally turn ideas into mentalities, and then that turn into ideologies, which from the debates rooms of international diplomatic meetings are put into practice, they cross the boundaries of time and become so deeply entrenched in the consciousness of those born under their sign that they take them as such and hardly can imagine that what today seems to be normal, the way the world works, in other times was made possible by the remarkable spirit of a chosen few.

As the whole, the volume "Vespasian V. Pella and the ideal of peace through law" is both a historical research document and also an instructiveeducational tool, a source of inspiration for educating and inspiring new generations of law specialists. It can be read as an arts album, as a source of information or as a testimony of change, about how great ideas come - from theory - to become reality.

It is worth noting the author's effort to gather archival testimonies and to dress them in the narrative thread of a story. The biographical data in the book is supplemented with explanations (with a special didactic tact, so that it can easily be understood by non-legal practitioners) extracted from the general theory of law, to fully underline the contribution made by Vespasian Pella in the field of international law. As a bonus for the reader, 
we note the beautiful writing style of the author, which brings to the reader a dynamic, exciting text, along with interactive graphics of great visual quality. That is why writing, conceiving and publishing the volume "Vespasian V. Pella and the Ideal of peace through Law" is a meritorious approach that must be credited with all appreciation.

\section{Acknowledgement}

This paper was elaborated within the doctoral research entitled "Social and Bioethical Acceptance of Techniques Related to Medically Assisted Human Reproduction in Romania", within and with funding by the doctoral scholarship awarded by the Doctoral School of Sociology, University of Oradea, Romania. The research is carried out in cocoordination with the University of Medicine and Pharmacy Grigore T. Popa from Iasi, Romania.

\section{References}

Ciuca, A. (2019). Vespasian V. Pella şi idealul păcii prin drept. Iasi, Romania: LUMEN Publishing House. 